\title{
Inclusion as Critique. Deconstructionist Approaches Exemplified through 'Care' of People with Cognitive Disabilities in Germany
}

\author{
Hendrik Trescher ${ }^{1}$ \\ ${ }^{1}$ Goethe-Universität Frankfurt, Frankfurt am Main, Germany \\ Correspondence: Hendrik Trescher, Goethe-Universität Frankfurt, Frankfurt am Main, Germany.
}

Received: July 7, 2017

Accepted: July 25, $2017 \quad$ Available online: July 31, 2017

doi:10.11114/ijsss.v5i8.2563

URL: https://doi.org/10.11114/ijsss.v5i8.2563

\begin{abstract}
The article builds on a reformulation of disability that construes disability as 'discoursive disability' (Trescher 2017d) and develops a conception of inclusion, which may be thought of as a deconstruction of barriers to participate in discourses and that aims at enabling access to discourses. I develop this perspective against the background of stationary housing in disability care. In this context, I refer to results of my study, Living space as pedagogic challenge. Institutional arrangement of residential home for people with disabilities' (Trescher 2017c), which documents that external and internal, (in)formally assigned practices manifest as 'disabling' and ultimately lead to a bureaucratic overdetermination of subjects. Inclusion in this regard means to deconstruct disabling practices, such as bureaucratic overdetermination, and thus constitutes a process, which runs counter to disability. Inclusion is critical, because it deconstructs barriers to participate in discourses and therefore ultimately transforms society.
\end{abstract}

Keywords: inclusion, discourse, foucault, cognitive disabilities, qualitative research, care system

\section{Overview}

Inclusion is a popular or may be in some ways fashionable term (Armstrong et al 2010), whose meaning is produced from different perspectives (academic and sociopolitical). The varieties of understandings of inclusion are manifold. "There are currently over 7000 books on inclusion listed on the Amazon website [and there are] numerous [of] journals publishing hundreds of articles discussing, defining, criticizing, explaining and theorizing" (Tomlinson 2017, 23) inclusion. A derivation of inclusion from theoretical engagement to empirical findings, however, is conspic uously absent. Regarding the German discourse Dannenbeck (2012) suspects that a "fuzzy use of the concept of inclusion distracts from its critical potential" (55; see also Dorrance/Dannenbeck 2013, 9f) ${ }^{1}$. The article proceeds from a revised concept of disability, which considers disability as disability to partake in discourse, and the results of a study on the living situations of institutionalized people with cognitive disabilities.

\section{Disability as Discoursive Event}

The problem with many extant conceptions of disability lies in according the condition of 'disabled' to the subject and, to the effect that people with disabilities are distinguished from people without disabilities. ${ }^{2}$ From this association emerge practices, which quasi-automatically unfold on the persons labeled as disabled. To untangle the status of 'disability' from the subject, a reformulation of traditional concepts of disability helps understand disability as disability of participation in discourse. Against the background of this conception, disability is not inherent to the subject, but rather a practice, as I stated prior to this ${ }^{3}$. Disability is, thus, not something that can be deemed a characteristic of subjects, but rather disability is always disability of discoursive participation, which occurs in everyday interactions and

\footnotetext{
${ }^{1}$ Some of the literature cited is available in German Language only. For a better understanding, the cited parts were translated into English. Nevertheless, the indication of source refers to the original version of the book in German.

${ }^{2}$ In a particularly strict sense, this distinction is maintained in diagnostic manuals such as the ICD-10 (International Statistical Classification of Diseases and Related Health Problems). But also in special needs/homeopathic discourses disability is maintained as a difference and, thus, often serves to justify a certain (pedagogic, therapeutic, psychological) intervention (Theunissen/Kulig 2011; Dörner 2010; Speck 2005).

${ }^{3}$ See for example Trescher $2017 \mathrm{a}, \mathrm{d}$.
} 
practices. Disability happens when a subject or a group is entirely or partially excluded from (respective) discourses through practices of power. Thus, disability is theoretically solvable by way of enabling access to discourses, which is discourse participation. From such a conception of disability also follows that people, who were so far not considered disabled, might be disabled in certain situations ${ }^{4}$ and, conversely, that people, who so far are considered disabled, might at times not be 'disabled'. Participation to discourse initially refers to 'general' discourses, which are distinct from 'specific' discourses. General discourses include all discourses to which every member in a society should have access (a normative component is hinted at here). Specific discourses, in contrast, describe those discourses, which require specific knowledge or qualifications and whose access is, therefore, regulated by certain conditions of participation. Discourses are general, if (hypothetically) any member of society has access and opportunity to participate. This requires that (close to) no "rarefaction among speaking subjects" (Foucault 1972, 224) occurs with a society. The (blurred) borders (Reckwitz 2008, 11) of a society, nonetheless, draw borders for a general discourse, whereby ultimately even speaking subjects within are constrained. In specific discourses, on the other hand, speaking subjects of a society may become scarce. The decision about which discourse is (or should be) either general or specific is a normative matter with social, cultural, and historical dimensions. Thus, it is ultimately a matter of justice, whether discourses are general or specific. A question of justice is always linked to a political decision (Forst 2005, 24ff).

\section{Disability as Governmental Practice and Result of Care Discourses}

\subsection{Federalized Care of People with Disabilities}

Care entails three aspects. First, care means 'custody and covering basic needs' and, thereby, designates basics for people to survive. Second, care includes a coordinated logistics in the sense of sustained supply. Third, care includes availability of resources beyond employment (such as retirement pension). In the context of stationary living for people with disabilities, all three aspects of care apply. ${ }^{5}$ The origins of institutionalized care for people with disabilities date back to the middle ages (Vanja 2007, 79) and so far, the "era of institutions" (Vanja 2007, 79) has not concluded. ${ }^{6}$ In Germany (today), care for people with disabilities is stipulated in the codes of social law ('SGB'). The net of social benefits (potentially) provided by the state is rather complex. Thus, SGB I deals with universal regulations from which claims may form that can be articulated by people with disabilities. The exact claims to care are distributed over up to eight of the remaining eleven codes of law. For people with increased need for support filing these claims becomes a bureaucratic challenge. In the context of care for institutionalized people with disabilities, relevant codes are $S G B I X$ (rehabilitation and participation of disabled people), SGB XI (long term care insurance) and SGB XII (social security). Therefore, people with disabilities are at the very least co-constituted by the comprehensive structure of bureaucratic processes. That co-constitution is intensified by jurisdiction - and the resulting dependence - of various agencies and institutions as well as the non-standardized codes of respective states for filing individual claims. In addition, it should be problematized that it is not always clear on which basis claims need to be filed. Stationary living, for example, requires clarifications in advance whether one deals with either a claim for care in fully stationary institution, an $S G B X I$ claim, or support for rehabilitation of people with disabilities, an SGB XII claim. Simply put, it has to be decided in what area the subject is 'more' disabled - in regard to care or to social problems. Care of people with disabilities is, therefore, in many ways a practice of negotiation.

\subsection{Governmental Care Practices}

Federal care systems regulate the structural framework of institutions for so-called disability aid and thus affect the lives of people, who live within those structures - be it by way of structural frameworks of a specific residential accommodation or by way of personnel, pedagogic or otherwise. The structures of care systems and its practices materialize as 'governing techniques' according to Foucault's concept of governmentality. Foucault describes governmentality as " $[t]$ he ensemble formed by the institutions, procedures, analyses and reflections, the calculations and tactics that allow the exercise of this very specific albeit complex form of power" (Foucault 1991, 102).

\footnotetext{
${ }^{4}$ One example for this is the general disenfranchisement of foreigners in Germany ( $\S 12$ of Federal Election Law $(B W a h l G))$. They are 'disabled' by way of according status to political participation.

${ }^{5}$ On the institutionalization of care practices see also Wansing 2005, $151 \mathrm{ff}$.

${ }^{6}$ Regarding the concept of institutions, it should be noted that there is a plethora of definitions with variations in "content and form of designations and criteria" (Schülein 1987, 9), so that "content designations remain conspicuously diffuse and vague" (ibid.) Following Esser (2000) 'institution' denotes "an expectation for adherence to certain rules that claim binding application" (Esser 2000,2). Institutions are in this context to be distinguished from regularity as well as from organizations (Esser 2000, 5ff).
} 
Governmentality is the essential type of enacting sovereignty. ${ }^{7}$ Governmentality signifies first and foremost a technique of leadership and is, thus, "the way in which one conducts the conduct of men" (Foucault 2008, 186). Governmentality entails a certain empowerment of subjects. In another sense, importantly, governmentality denotes those procedures, whereby subjects (sovereigns) deliberately affect the behavior of others and/or their own. Subjects are discoursively (co-)produced by way of go verning techniques (see here Lemke 2014, Angermüller/van Dyk 2010). This affects, on the one hand, a superordinated level of state rulers and 'the citizen', who has certain obligations (e.g. obligation to register) and must observe the laws, wherein he may move 'freely'. On the other hand, it also affects, on a structurally subordinated level, those, who impose rules and codes of conduct in a specific institution, and those, who have to observe them, that is the residents of an institution. This can be illustrated using the case of institutionalized (stationary) living for people with disabilities. The state provides certain specifications, within which residential institutions may operate 'freely', or which they may interpret, but which also lead to the generation of specific care institutions. Operated by internal and external planning, these institutions, in turn, affect subjects and co-constitute them in a distinct way. Governmental techniques play a role specifically in the context of pedagogic relationships between caretakers and care recipients. Such "processes of subjectivation have to be reconstructed systematically as processes of ambivalent simultaneity of external and autonomous leadership" (Kessl 2006, 72). The go vernmental structures weave a complex, closely meshed web around people with disabilities. They materialize in a myriad of institutions, positions and persons that are each responsible for a job in care and that are, in addition, interconnected and codependent. For example, it is often the case that a person with disabilities lives in a residential home, in which several professions are employed in specific areas (e.g. pedagogic staff, 'specialized' or 'general' staff, maintenance, cleaning, janitorial, care personnel, etc.). In addition, there might be external nursing services, such as therapists, doctors, legal custodians, and others. Often the affected person with disability is employed in a work shop (' $W f b M$ '), in which others assume responsibility, or the person frequents a recreational context, in which again others assume guardianship. Thus, "the resident's body is divided into jurisdictions, in which personnel acts" (Trescher 2017c, 82). Such a parceling requires a considerable effort of documentation, whereby the subject is surveilled and potentially regulated. Already this brief account shows the possibly rigorous effort in terms of socialized care and bureaucracy commanded by the object of disability in Germany. ${ }^{8}$ In what follows, the article will further document these findings. It will be critical to work out the ambivalent relationship between the theoretical notion of living in a residential home and the actual arrangement of living space for people with disabilities.

\section{Living as Practice of Appropriation}

'Wohnen' (to reside) refers to the original meaning of "lieben (to love), schätzen (to appreciate)" (Kluge 2002, 994) as well as to the "inextricable unity of residing and living" (Hasse 2009, 26). The term to reside is inseparable from the notion of space (Thesing 2009, 26). According to Löw (2001), 'space' signifies a "relational ordering of social goods and people (creatures) in places" (224). Space, then, has structuring functions as well as a dimension for action (Löw 2001, 166; Trescher 2017c, 20f) and, thus, generates "discourses of negotiation, which determine the arrangement and extent of space" (Trescher 2017c, 20). Living is not tied to a space, but rather is expressed through a form of local, but also social connection and affiliation (Hasse 2009, 26f; Trescher 2017c, 21f; 2017b). On that view, living is "not any kind of spatio-physical being in the world. It is rather characterized by familiarity and a sense of belonging to a place and its region" (Hasse 2009, 33). Living space is a place for social togetherness and offers fundamental opportunity for designing communal practices (Hasse 2009, 28f). At the same time, personal living space is a private room for retreat and not freely accessible without invitation. ${ }^{9}$ As I pointed out these (social) practices of appropriation in conjunction with an active arrangement of living space are important characteristics of 'living ${ }^{10}$. To provide people with disabilities with a 'living space', that is a place they may appropriate (individually and socially), is according to this view the meaning of residential institution.

\footnotetext{
${ }^{7}$ Foucault distinguishes governmentality from forms of rule, sovereignty, and discipline. Governmentality is "[t $t$ he tendency which, over a long period and throughout the West, has steadily led towards the pre-eminence over all other forms (sovereignty, discipline, etc.) of this type of power which may be termed government, resulting, on the one hand, in the formation of a whole series of specific governmental apparatuses, and, on the other, in the development of a whole complex of savoirs" (Foucault 1991, 102f).

${ }^{8}$ This affects people with a high need of assistance in particular (Trescher 2017c, 22ff).

${ }^{9}$ On the definition of 'private' as well as the correlation between privacy and dignity, see Trescher 2015a.

${ }^{10}$ See for instance Trescher 2017c, 20f; $2017 \mathrm{~b}$.
} 


\section{The Project}

Within the project 'Living space as pedagogic challenge. Institutional arrangement of residential home for people with disabilities' I explored the guiding question, how living in institutions of disability care affects the living situation of people with disabilities. The methodological setting for dealing with this question involves a multi-method combination of two research perspectives, namely, on the one hand, an objective analysis of structural conditions in residential homes and, on the other, an analysis of subjective-affective experiencing of the people living in those homes. This multi-method approach allows illuminating the living situations of institutionalized people with cognitive disabilities. Two contrasting residential homes were selected as the object of study (one traditional residential home and one apartment arrangement).

\subsection{Structural Analysis}

The structural analysis followed the procedures of objective hermeneutics (see on method Oevermann 2002a; see on application Trescher 2017c, 46), which by way of reconstructing objective meaning allow for disclosure of latent semantic structure and, thus, "reveal the principles operating behind the appearances" (Oevermann 2002a, 1). In both residential homes structural data, such as floor plans and timetables organizing routines of care and assistance, were gathered and used for structural analysis. Moreover, conversational interviews with staff members and (former) residents were conducted and, likewise, sequentially reconstructed using the methods of objective hermeneutics.

\subsection{Affective Revisiting}

For the scenic subjective-affective analysis I developed the method of 'affective revisiting', derived from psychoanalysis (Trescher 2017c, 61ff). Central to this method is experience - concretely for present purposes experiencing daily routines in the residential home. This operation makes it possible to reflexively recapitulate by way of establishing an affective-emotional approach to observations. The procedure involves five steps (observing, replay, record, revisit, and draft) that are operationalized within a research group. Condensed, affective interpretations offer access to the experiences of the observed person. Observational records from residential homes make up the foundation of affective revisiting.

\section{Disability as Practice Using the Example of Residential Housing in Disability Care}

\subsection{External and Formal Practices in Residential Housing in Disability Care}

Living conditions for people with disabilities are enmeshed into the web of care systems. Thus, certain specifications emerge that result in external and formal practices, which in turn affect institutional daily routines. Exemplary for the entire bureaucratic superstructure, the article now considers two elements that (co)constitute institutional practice.

\section{Legal Specifications of Spatial Arrangement}

Arrangement of housing and housing units is regulated through various laws and statutes. Accordingly, the contractual code of housing and assistance (WBVG; former Heimgesetz) specifies the contractual regulations of residential housing (with different regulations in each of the 16 federal states). Edicts regarding construction and infrastructure can be found among the edicts of construction minimal requirements for nursing homes and residential care homes for adults. Among others, these edicts hold that "floor decking in rooms and other areas used by residents must be skid-proof" (§5) or that walls and staircases must have handrails on both sides ( $\$ 3$ sec. 3). By way of (mandatory) installation of intercoms, at least in rooms for people in need of care (\$7), surveillance structures are built in. The arrangement of living space is, then, (co)determined from various parties, to the effect that living as practice of appropriation is massively constrained.

\section{Aspects of Allotment of Need for Care - 'Planning Participation'}

Likewise, the allotment of need for care is regulated differently among Germanys 16 federal states. This section covers exemplarily the so-called integrated participation plan ('ITP'), an instrument of the state welfare association of the federal state Hessen. This association is widely considered 'progressive' (see among others Rölke 2013; Jürgens 2015). ITP, which has so far only been tested in a few other model regions (cf. Rölke 2013, 116), is supposed to register resources, environmental factors, and need for care of people with disabilities. The basis for ITP consists of "wishes, imaginations, and needs of clients" (Gromann 2010,4). On that basis, short and long-term goals are determined and extant skills and barriers are assessed (LWV Hessen 2015,7). The core areas are 'housing' and 'work/vocation/daily routine'. A potential problem with this distinction is that these areas are not always clearly separable. This applies for example (in the case of people with cognitive disabilities) specifically to people with pensions, who are increasing in numbers (cf. Grunwald et al. 2013; Wiese et al. 2012, 571; Köhncke 2009, 28f; Mair/Hollander 2006, 58) for 
structuring activities offered in the institution are often not perceived distinct from regular daily routine ${ }^{11}$. A basic problem is that processing the ITP might involve several competing interests. For it is the case that the more pronounced the constraint of an affected person, the higher may be their claim to financial assistance. The benefit, however, is not necessarily paid to the person, but often, especially in the case of residential housing of people with cognitive disabilities, to the residential home or its administration. Ultimately, the logic of ITP creates a financial interest on the part of the institution or the administration for the resident's need for care to be as high as possible. This self-reproducing logic of the care system arguably generates external and formal practices that massively constrain and/or disable the daily routine of many people with disabilities (in particular, people with cognitive disabilities).

\subsection{Internal and Formal Practices in Residential Homes of Disability Care}

Aside from external and formal practices there are internal specifications. These are produced by the institutions and aim at optimization procedures and allocate personnel effectively according to resources. There are comprehensive plans, which in part translate to (often far-reaching) constraints of resident's daily routine. In schedules for showering, shopping, and eating daily practices are at times planned along general lines, at other times structured rigorously. Another formation of internal and formally stipulated practice holds, for instance, that offices are frequently situated in residential areas. Placing offices in otherwise private spaces produces areas that are inaccessible to residents. This creates surveillance structures, which further contribute to the resident's objectification. Living as a practice of appropriation is, thereby, disabled.

The structural and practical arrangement of so-called key workers ('assistants') is particularly ambivalent. Basically, it appears sound to designate to each resident a staff member, who is primarily responsible for that person's needs and interests. At the same time, specific responsibilities emerge from this arrangement, which lead to further codependence on the part of the residents. For example, residents may only observe certain, otherwise considered normal, appointments only in the company of their respective assistant and are, therefore dependent on that staff member's schedule. Residents are, thus, inhibited in their economy of action and spontaneity (see Goffman 1968). What is more, the arrangement of a key worker system is conducted primarily on a technical basis. The assistants are not tasked with individual and extensive social or psychosocial care, but handle primarily organizational and bureaucratic matters. Relationships between staff members and residents are, therefore, characterized by object-oriented rationality, equivalent to a relationship of service. Unfortunately, due to this lived service relationship residents only contingently experience recognition and appreciation. Another problem seems to be that staff members internalize bureaucratic structures, such as stipulated by ITP, and adjust their actions accordingly. This can be shown using a brief example. At a feedback workshop with staff members of a residential home, I thematized the tendencies of dilapidation in residential homes. One staff member comments that in no way should that be considered intentional dilapidation, rather a form has been filled out for the janitor several times, so that he (in a specific room) may work on renovation. No staff member seriously entertains the notion of doing something to improve the condition of the room (already a paint job to cover a dirty spot would go a long way), because the internal specifications and procedures of the institution have manifested already ${ }^{12}$. The maxim is, therefore, a bureaucratically oriented 'care pragmatism'.

\subsection{Internal and Informally Stipulated Practices in Residential Homes in Disability Care}

Aside from formal practices, there are informal practices that affect the daily routine of an institution. Internal and informal practices signify those practices that are not stipulated by the institution or the administration, but that derive implicitly from their stipulation. This applies primarily to optimizing routines within the institution. One example in this context is the optimization of documentation practices by way of installing an office space in residents' living room, so that bureaucratic tasks, such as documentation, may be completed on-site and that staff members do not need to leave the residential unit or plan for additional office hours. One staff member comments in this regard: "We do the documentation here in the group room [meaning the residents' living room]; we have placed a desk there. It's not ideal not to be able to lock anything away, other than in the desk. But ok, that's not uncommon here, that the rooms are not ideal " (M-1;1.348-351). In this way, the residents' living room - otherwise a private room - becomes institutionalized and turned into office space for staff members. Another informal practice is the optimization of care benefits. In the morning staff members wake up residents, so that they are ready for care. Hours of sleep are, thus, not oriented primarily according to individual needs, but rather according to the arrangement of the staff schedule. One staff member describes: "Sometimes the night shift covers morning care, so that the day shift can finish faster" (M-3; 1. 187-188). It is not uncommon that residents are prepared for bed early in the evening, because staff members already clock out right after dinner. Another staff member comments: "After 6 it's dinner time and then comes going to bed business" (M-1; 1 .

\footnotetext{
${ }^{11}$ For further information, see the project "Leisure as Window to Inclusion” (Trescher 2015b, 206ff).

${ }^{12}$ See respectively Trescher $2017 \mathrm{c}, 198 \mathrm{f}$.
} 
275-276). One resident, who is portrayed as intensive regarding care, is put to bed at $7 \mathrm{PM}$ and receives a prescription that lets him sleep through the night. One consequence is that institutionalized people with disabilities, like the above resident, have structural difficulties or are even denied participation in routine and inclusive recreational activities, which largely take place in the evening ${ }^{13}$. The subject that is considered disabled is, then, disabled by that practice in its participation in society. It should be emphasized, however, that these practices are not simply invoked by staff members. Rather, they develop from the intrinsic logic of the institution, which is ultimately stipulated by the structure of external care and, thus, leads to a bureaucratic overdetermination of subjects, which act (pedagogically) under the protectorate of disability care.

\section{Bureaucracy as Disabling Practice}

People, who are being cared for in institutions of disability care, but also those, who work there pedagogically, are bureaucratically overdetermined through a tightly-knit system. A 'service', which is not documented, counts as not provided and if the schedule for showering is not observed, it is considered uncooperative among the acting subjects. These governmental structures limit significantly the residents' personal economy of action. The people in the institution are bureaucracy-disabled. Referring back to the above practices within residential care of people with disabilities it can be summarized that external and formal as well as internal and (in)formal practices regulate the residents' lives in the institution and, thus, contribute to disabling living as a practice of appropriation. Using living space as a place that allows for individual design, uninhibited self-actualization, and private retreat (Hasse 2009, 29ff) is only a contingent possibility for institutionalized people with disabilities, as the subject is bureaucratically fragmented and, thus massively constrained in its personal economy of action as well as in its personal development. The practices aimed at the subject ultimately lead to a bureaucratic overdetermination, which is evinced not merely, but especially so, in the copious amounts of forms and files regarding the person. Disability, thereby, becomes an object of administration through institutional staff - disability becomes disability of bureaucracy. People, who depend extensively on care systems (for example people with 'severe' disability), are particularly affected. Abrams (2015) gets right to the point, when he writes, "filling out bureaucratic forms is an essential part of (Western) disabled existence" (Abrams 2015, 13). As I mentioned by way of these practices, the subject is bureaucratically and administratively reduced to data sets and disability becomes life's benchmark ${ }^{14}$. These practices reproduce disability in many ways as „measurable problem” (Titchkosky 2007, 48) and demonstrate that " $[\mathrm{t}] \mathrm{o}$ be disabled is to be mapped, charted, poked-and-prodded - and then: inscribed" (Abrams 2015, 15). This is particularly obvious using the above example of enforced documentation within the institution, causing staff members to primarily work for 'the file' - and not for the residents. "This bureaucratic and administrative discourse (re)produces subjects as singularized objects" (Trescher 2017b). The massive bureaucratic superstructure impacts not merely the subject in care, but also those who (otherwise) act pedagogically in the institution, because the plethora of stipulations, to which staff members need to adhere - among others above mentioned enforced documentation - considerably limits pedagogic efforts in the sense of a reflexive relationship (Oevermann 1996). Bureaucratic disabling occurs in two ways: On the one hand, it regulates and surveils minutely the life of the affected through stipulations and regulations, which need to be observed, resulting in internal and (in)formal practices. On the other hand, bureaucratic stipulations use up resources, in that staff members spend a lot of their time at work dealing with matters of administration and documentation, which ultimately prevents professional, pedagogic action. ${ }^{15}$ The extent of such, for the most part externally prescribed, focusing on completing administrative tasks become clear in an interview with a former resident of a (relatively open) home: "And what sucked about the residential home was, oh, yes em, rough word, but it's true, that caregivers hardly had time for us. Because whenever someone wanted something, for example, is there toilet paper? 'Busy', 'dish soap?', 'Busy'. Always the same excuse. And all they did was sitting in their offices typing on their PCs" (B-2; 1. 222-225). This predominance of bureaucratic activities ultimately means a managerialization of the matter 'disability', which in turn causes an extensive alienation of those, who act (pedagogically) (whose activities hardly satisfy pedagogic maxims (among others Bernhard 2011)) from those, for whom these pedagogic activities are generated. ${ }^{16}$ From the alienation to their work emerges an alienation in the

\footnotetext{
${ }^{13}$ This was a major result of the study "Leisure as Window to Inclusion" (Trescher 2015b, 140f).

${ }^{14}$ I developed this thought especially in Trescher $2017 \mathrm{c}$.

${ }^{15}$ This refers to a definition of profession following Oevermann (1996; 2002b), which understands pedagogic action primarily as reflexive and interactive action, which in turn enables a "practice of relationship" (Oevermann 1996, 115) with those who receive care (see also Trescher 2016).

${ }^{16}$ In this context an economic analysis about the expenses necessary for bureaucratic practices in this complex system from care agencies to administration in each federal state, to state welfare associations, individual bureaucratic structure within administrations or institutions, to staff costs in each respective institution - would be rather fascinating. To the
} 
pedagogic relationship ${ }^{17}$. This also means that pedagogic action, in the sense of representative or mutual dealing with crisis, hardly takes place anymore, because practices are stipulated to the extent that spaces for self-reliant pedagogic activity of 'professionals' (to what extent they can be designated 'professionals' is another matter) are significantly reduced. Empirical results of interviews with staff members in the context of residential homes also reveal that staff members repeatedly find niches in daily routines, in which they can arrange moments of reflexive pedagogy and encounter the residents. Staff members, thus, turn into resisting subjects, which confront the predominance of the bureaucratic and administrative superstructure. Ultimately, bureaucratic structures in their encompassing power can be identified as barriers to discourse, for they a) technically reduce the subject and its individual needs and, therefore, b) disable the pedagogic practice, which ideally should result in empowering subjects (this also applies to the close stipulated pedagogic relationship between staff members and residents), and c) through these practices (re)produce disabled identities. Due to these practices, people with disabilities can often develop only within the narrow borders of the care system and, accordingly, cannot partake in the practices of larger society. It is, therefore, necessary to deconstruct those structures that have been identified as barriers to participation in discourse. A notion of inclusion is required.

\section{Inclusion}

The previous section has demonstrated how disability occurs discoursively in the context of residential homes of disability care. Referring back to the above definition of disability, which is independent of the subject, the article now sketches an understanding of inclusion, which counters the occurrence of 'discourse disability'.

\subsection{Inclusion as Deconstructive Practice}

Based on the definition of disability as disability to participate in discourse, which happens whenever subjects encounter barriers to participate in discourse, inclusion is conceptualized as process or practice of deconstructing those barriers. Inclusion is thought as a process running counter to disability. At the end of that deconstruction process of barriers to discourse emerge opportunities of inclusion. It would seem obvious that such a process involves challenges and that it might be crisis-laden for the subjects and discourses involved, since initially routinized practices and paradigms need to be abandoned. Ultimately, inclusion cannot merely be 'generated', but rather needs to occur in practices of living. It is important to undo anxieties and reservations and to reflect on perspectives. Thus, inclusion always involves shifts in discourse. Such a shift in discourse is presented exemplarily for the object of 'residential living of people with cognitive disabilities'. In that context, the deconstruction of barriers to discourse must occur on several levels.

\section{Deconstructing Governmental Practices}

Governing techniques of social welfare states, as was shown, causes certain subjects addressed as recipients of services to have their economy of action significantly reduced. Subjects as "their own manager" (van Dyk/Angermüller 2010, 10) only have available a severely limited space for the business of their self-actualization. The governmental steering, which governs through several levels of institutions and discourses and, thus, (re)produces subjects in a specific way, occurs by allowing only those narrow spaces for the subjects' self-actualizing. In the concrete case of residential living in homes of disability aid this happens when reduced evening care prevents (routine, nightly) recreational activities. This is precarious, since the area of leisure has an especially high potential for inclusive togetherness. The narrow borders in residential homes, thus, act as "barriers for inclusion", as I term it, and dis able an inclusive participation in practices external to the institution. The deconstruction of governmental techniques can never succeed entirely, but for the current purpose involves the de-bureaucratization of living spaces, which creates hidden areas outside the purview of the state. For the state, this means to act no longer by the maxim of a perfectly surveilling care of the body, but rather to accept "the risk of not-knowing" which accords personal economy of action and dignity to the subject.

\section{Deconstruction of Speechlessness}

Inclusion also means in this case a deconstruction of barriers to (general) discourses. Such a constraint occurs through exclusionary practices that determine which subjects can speak within a discourse (whereas in this context 'speaking' is not exclusive to verbal communication) and which subjects cannot. This shortage or selection of speaking subjects in a

overhead of bureaucratic expenses, one challenge might be to ask, what exactly arrives at the subjects in terms of resources and care services.

${ }^{17}$ See here extensively Trescher $2017 \mathrm{c}, 185 \mathrm{f}$. 
discourse is a controlling procedure (Foucault 1972, 224ff) ${ }^{18}$. The discourse demarcates who is capable of discourse and can, therefore, speak in its confines. "None may enter into discourse on a specific subject unless he has satisfied certain conditions or if he is not, from the outset, qualified to do so" (ibid., 224f). The disenfranchisement from elections of foreigners, but also that of people under extensive care, may be considered as examples (Federal Election Law BwahlG $\S \S 12$ and 13). These persons are prediscoursively manifested as 'voiceless' and are disabled to speak in discourse. Powerful mechanisms in this context are the ritual and the doctrine. The ritual defines which stipulations rule of those who are speaking in a discourse, "it lays down gestures to be made, behavior, circumstances and the whole range of signs that must accompany discourse" (Foucault 1972, 225). The doctrine stipulates who is subsumed under which category (e.g. association with category 'person with cognitive disabilities') and is, thus recognizable as 'the sign, the manifestation and the instrument of a prior adherence" (ibid., 226). Such affiliation to the care system by way of adopting the status 'person with cognitive disabilities' or 'recipient of care' complicates access to universal discourses. This happens when utterances of people with cognitive disabilities are not taken seriously based on that status. A shift in exclusionary discourse practices involves a broadening of speaker roles to (ideally) all subjects as well as the empowerment of all subjects to speech and the deconstruction of certain doctrines. This coincides with the deconstruction of certain governmental practices. It can be illustrated by referring to the above example of the care system disabling leisure time of people with cognitive disabilities, for consistent treatment of people as people with cognitive disabilities produces their subjectivity accordingly. As I pointed out many institutionalized people with cognitive disabilities do not express their interest in recreational activities, since it is not intended that they do in respective institutions ${ }^{19}$. Rather, the role of people, who live in these places, appears to be structured such that they wait for recreational offers by the institution. As a consequence, they might not know recreational activities from otherwise routine practices of living (Kreuzer 2000, 153ff). Cognitive disability is here inscribed as status (which is primarily characterized by dependence) into the subject - also, because the care system intends it that way. Aside from practices that determine which persons can speak within a discourse, inclusion also pertains to practices that stipulate what is thematized in a discourse. Inclusion means, therefore, also deconstructing normalizing practices of discourse, which determine which practices and topics are common and acceptable in a discourse, so that an expansion of these discourses is possible. This applies primarily to deconstructing the ban, which regulates discourses via "covering objects, ritual with its surrounding circumstances, the privileged or exclusive right to speak of a particular subject" (Foucault 1972, 216).

\section{Deconstruction of Exclusionary Systems}

Another exclusionary mechanism is 'the division of madness" (Foucault 1972, 219). Subjects construed as 'mad' are excluded from discourse: "a man was mad if his speech could not be said to form part of the common disc ourse of men. His words were considered nul and void, without truth or significance, worthless as evidence, inadmissible in the authentification of acts or contracts" (ibid., 217). Even when "strange powers" (ibid., 217) are ascribed to the word of the madman and he is believed to "revealing some hidden truth, of predicting the future, of revealing, in all their naivete, what the wise were unable to perceive" (ibid.), his word still is not part of the discourse, "whether excluded or secretly invested with reason, the madman's speech did not strictly exist" (ibid.). This applies especially to people with cognitive constraints (aside from people with cognitive disabilities, for instance, also people with dementia). In this context, I was able to show within the project 'Contexts of life. Living conditions of people with dementia in residential homes' that residents of these institutions converse about their daily routines and interact with their environment, but that they are hardly heard by staff members ${ }^{20}$. Moreover, the "will to truth" (ibid., 218) marks an exclusionary mechanism, which regulates what can be said in a discourse. Accordingly, scientific discoveries represent the acceptance of 'new truths' (ibid., 218f). "[T] his will to truth, like the other systems of exclusion, relies on institutional support: it is both reinforced and accompanied by whole strata of practices such as pedagogy - naturally" (ibid., 219). A normalizing discoursive practice "formulates and defines norms, which allow bifurcations normally and abnormally and which operate in institutional practices" (Lemke 2014,96f). This can be illustrated using the example of customary norms, as they occur as normalized practices during a visit to a restaurant. ${ }^{21}$ The people, who frequent a restaurant, underlie implicit norms, which generate certain behavior that can be considered 'customary etiquette'. A deconstruction of such customary

\footnotetext{
${ }^{18}$ In terms of 'speechlessness' of groups and individuals see Spivak's book “Can the Subaltern Speak?" (1988), in which she elaborates how the so-called 'subaltern' are hindered from partaking in discourse. Continuatively see Butler's concept of performative speech act (i. a. Butler 1999).

${ }^{19}$ See for further information Trescher 2015b, 208f, 2017a.

${ }^{20}$ I provide further information on the study referred to in Trescher $2013 \mathrm{~b}$.

${ }^{21}$ It should be noted that such customary norms depend on social, cultural, and historical variables.
} 
etiquette allows other normalized practices, such as for instance help with eating a meal (even for adults). Such support would, then, be anchored as normal in the discourse and would not cause any irritation, as it is to be expected in contemporary practices. A respective deconstruction engages traditional customs and rites and certainly results in irritation of all those affected over the course of that process.

\section{Inclusion is Critique}

To conclude, inclusion in this context is not sketched as a moral notion, which holds that all people should participate in all discourses. Rather, the aim is to conceptualize inclusion as a process counter to disability. Inclusion is, therefore, a practice that confronts different disabling practices. In that sense, inclusion is critical, because it questions governmental techniques ${ }^{22}$. It captures practices of domination and exclusion and deconstructs them in practices of living. Inclusion changes society and is, thus, always critique of society. "To take inclusion seriously necessarily involves steadily formulating critique of societal and institutional frameworks and, thus, to take seriously the politicizing of one's own actions" (Seifert 2013). This was meant to materialize in the present article, which demonstrated the almost inevitable connection of the label 'disabled' to - and primarily through - entry into the system of disability care and all its implications. Once people fall under the encompassing structures of disability care and its institutions, their lives are henceforth governed by a high degree of surveillance and regulation. Using the example of residential housing in institutions of disability care, the article demonstrated that such practices of surveillance and regulation span from allocating service (illustrated by way of integrated participation in planning) to the extensive management of all personal matters (such as hygiene, daily routine, recreational activities). There is, then, a need for a shift in discourse that makes possible to challenge and break up traditional practices (such as total structures of disability care or customary norms). In the course of such processes, reservations and anxieties of the affected are to be expected naturally. Accordingly, it is a pedagogic, but also societal task to guide these processes and to reduce concerns. Importantly, in this context, points of contact between people with and without (cognitive) disabilities need to be established, so that ultimately inclusion can be advanced as a societal process.

\section{References}

Abrams, T. (2015). Disability and bureaucratic forms of life. Nordic Journal of Science and Technology Studies, 3(1), 12-21. https://doi.org/10.5324/njsts.v3i1.2153

Angermüller, J., \& van Dyk, S. (Eds.). (2010). Diskursanalyse meets Gouvernementalitätsforschung. Perspektiven auf das Verhältnis von Subjekt, Sprache, Macht und Wissen. Frankfurt am Main: Campus.

Armstrong, A. C., Armstrong, D., \& Spandagou, I. (2010). Inclusive Education: International Policy and Practice. London: Sage.

Bernhard, A. (2011). Pädagogisches Denken. Einführung in allgemeine Grundlagen der Erziehungs- und Bildungswissenschaft. Baltmannsweiler: Schneider Verlag Hohengehren.

Butler, J. (1999). Gender Trouble. Feminism and the Subversion of Identity. New York: Routledge.

Dannenbeck, C. (2012). Wir kritisch ist der pädagogische Inklusionsdiskurs? Entpolitisierungsrisiko und theoretische Verkürzung. In K. Rathgeb (Ed.), Disability Studies. Kritische Perspektiven für die Arbeit am Sozialen (pp. 55-67). Wiesbaden: VS.

Dörner, K. (2010). Leben in der „Normalität“ - ein Risiko? In G. Theunissen, \& K. Schirbort (Ed.), Inklusion von Menschen mit geistiger Behinderung. Zeitgemäße Wohnformen - Soziale Netze - Unterstützungsangebote (pp. 97-102). 2. Auflage, Stuttgart: Kohlhammer.

Dorrance, C., \& Dannenbeck, C. (2013). Doing Inclusion. Zur Einführung in den Band. In C. Dorrance, \& C. Dannenbeck (Ed.), Doing Inclusion. Inklusion in einer nicht inklusiven Gesellschaft (pp. 9-12). Bad Heilbrunn: Klinkhardt.

Esser, H. (2000). Institutionen. Frankfurt am Main: Campus.

Forst, R. (2005). Die erste Frage der Gerechtigkeit. APuZ. Aus Politik und Zeitgeschichte, 37, 24-31.

Foucault, M. (2008). The Birth of Biopolitics. Basingstoke, Hampshire: Palgrave Macmillan.

Foucault, M. (2007). What is Critique? In Lotringer, S. (Ed.), The Politics of Truth (pp. 41-81). Cambridge, Mass, and London: The MIT Press.

Foucault, M. (1991). Governmentality. In G. Burchell, C. Gordin, \& P. Miller (Eds.), The Foucault Effect. Studies in Governmentality with two Lectures by and an Interview with Michel Foucault (pp. 87-104). Chicago: The University of Chicago Press.

\footnotetext{
${ }^{22}$ As Foucault would put it: Inclusion as critique is "the art of not being governed quite so much" $(2007,45)$.
} 
Foucault, M. (1972). The Archaeology of Knowledge and the Discourse on Language. New York: Pantheon Books.

Goffman, E. (1968). Asylums. Essays on the Social Situation of Mental Patients and Other Inmates. Chicago: Aldine.

Gromann, P. (2010). Manual Integrierter Teilhabeplan Hessen (ITP) Hessen, Version 2.1. Retrieved from http://www.lwv-hessen.de/files/272/Manual__Handbuch__fuer_den_ITP_Hessen.pdf

Grunwald, K. et al. (2013). Demenz bei Menschen mit geistiger Behinderung. Eine empirische Bestandsaufnahme. Bad Heilbrunn: Klinkhardt.

Hasse, J. (2009). Unbedachtes Wohnen. Lebensformen an verdeckten Rändern der Gesellschaft. Bielefeld: transcript. https://doi.org/10.14361/9783839410059

Jürgens, A. (2015). Vorwort. In Landeswohlfahrtsverband Hessen (Ed.), Der integrierte Teilhabeplan (ITP) in Hessen. Ein Instrument zur Planung der Unterstützungsleistungen für behinderte Menschen. Retrieved from http://www.lwv-hessen.de/files/266/ITP_A5_20_04_2015.pdf

Kessl, F. (2006). Soziale Arbeit als Regierung - eine machtanalytische Perspektive. In S. Weber, \& S. Maurer (Eds.), Gouvernementalität und Erziehungswissenschaft. Wissen - Macht - Transformation (pp. 63-75). Wiesbaden: VS. https://doi.org/10.1007/978-3-531-90194-7_4

Kluge, F. (Ed.). (2002). Etymologisches Wörterbuch der deutschen Sprache, 24. Aufl. Berlin [u.a.]: Walter de Gruyter.

Köhncke, Y. (2009). Alt und behindert. Wie sich der demografische Wandel auf das Leben von Menschen mit Behinderungen auswirkt. Berlin. Retrieved from http://www.berlininstitut.org-/fileadmin/user_upload/Alt_behindert/Alt_und_behindert_online.pdf

Kreuzer, M. (2000). Zur Bedeutung und Fachlichkeit der Freizeitarbeit in Wohneinrichtungen. In R. Markowetz, \& G. Cloerkes (Eds.), Freizeit im Leben behinderter Menschen. Theoretische Grundlagen und sozialin tegrative Praxis (pp. 151-170), Heidelberg: Universitätsverlag C. Winter.

Lemke, T. (2014). Eine Kritik der politischen Vernunft. Foucaults Analyse der modernen Gouvernementalität. 6. Auflage, Hamburg: Argument.

Löw, M. (2001). Raumsoziologie. Frankfurt am Main: Suhrkamp.

LWV Hessen. (2015). Der Integrierte Teilhabeplan (ITP) Hessen. Ein Instrument zur Planung der Unterstützungsleistungen für behinderte Menschen. http://www.lwv-hessen.de/files/266/ITP_A5_20_04_2015.pdf (zuletzt am 01.02.2017).

Mair, H., \& Hollander, J. (2006). Den Ruhestand gestalten - Bericht über das Modellprojekt „Unterstützer Ruhestand von älteren Menschen mit Behinderungen“. Heilpädagogik online, 06, 58-79. Retrieved from http://www.heilpaedagogik-online.com/2006/heilpaedagogik_online_0106.pdf

Oevermann, U. (1996). Theoretische Skizze einer revidierten Theorie professionalisierten Handelns. In Combe A., \& W. Helsper (Eds.), Pädagogische Professionalität. Untersuchungen zum Typus pädagogischen Handelns (pp. 70-182). 1. Aufl. Frankfurt am Main: Suhrkamp.

Oevermann, U. (2002a). Klinische Soziologie auf der Basis der Methodologie der objektiven Hermeneutik. Manifest der objektiv hermeneutischen Sozialforschung. Unveröffentlichtes Manuskript. Frankfurt am Main. Online verfügbar unter

http://www.ihsk.de/publikationen/Ulrich_Oevermann-Manifest_der_objektiv_hermeneutischen_Sozialforschung.p df (zuletzt am 20.06.2017).

Oevermann, U. (2002b). Professionalisierungsbedürftigkeit und Professionalisiertheit pädagogischen Handelns. In M. Kraul, W. Marotzki, \& C. Schweppe (Eds.), Biographie und Profession (19-63). Bad Heilbrunn: Klinkhardt.

Reckwitz, A. (2008). Unscharfe Grenzen. Perspektiven der Kultursoziologie. Bielefeld: transcript. https://doi.org/10.14361/9783839409176

Rölke, D. (2013). Integrierte Teilhabeplanung. In C. Dorrance, \& C. Dannenbeck (Eds.), Doing Inclusion. Inklusion in einer nicht inklusiven Gesellschaft (pp. 114-118). Bad Heilbrunn: Klinkhardt.

Schülein, J. A. (1987). Theorie der Institution. Eine Dogmengeschichtliche und konzeptionelle Analyse. Opladen: Westdeutscher Verlag.

Seifert, R. (2013). Eine Debatte revisited: Exklusion und Inklusion als Themen der Sozialen Arbeit. Zeitschrift für Inklusion (online).

Speck, O. (2005). Menschen mit geistiger Behinderung. Ein Lehrbuch zur Erziehung und Bildung, 10. Auflage, München: 
Reinhardt.

Spivak, G. C. (1988). “Can the subaltern speak? “ In C. Nelson, \& L. Grossberg (Eds.), Marxism and the Interpretation of Culture (pp. 271-313). Basingstoke: Macmillan Education. https://doi.org/10.1007/978-1-349-19059-1_20

Thesing, T. (2009). Betreute Wohngruppen und Wohngemeinschaften für Menschen mit geistiger Behinderung . Freiburg im Breisgau: Lambertus.

Theunissen, G., \& Kulig, W. (2011). Empowerment und Sozialraumorientierung in der professionellen Unterstützung von Menschen mit Behinderungen. In D. Lampke, A. Rohrmann, \& J. Schädler (Eds.), Örtliche Teilhabeplanung mit und für Menschen mit Behinderungen (pp. 269-284). Wiesbaden: VS. https://doi.org/10.1007/978-3-531-93486-0_20

Titchkosky, T. (2007). Reading and writing disability differently. The textured life of embodiment. Toronto, Buffalo: University of Toronto Press.

Tomlinson, S. (2017). A Sociology of Special and Inclusive Education. New York: Routledge.

Trescher, H. (2017a). Behinderung als Praxis. Biographische Zugänge zu Lebensentwürfen von Menschen mit "geistiger Behinderung". Bielefeld: Transcript. https://doi.org/10.14361/9783839439715

Trescher, H. (2017b). Zur bürokratischen Überformung der Subjekte. Wohnen in der stationären Alten- und Behindertenhilfe. In M. Meuth (Ed.), Wohn-Räume und pädagogische Orte (pp. 245-266). Wiesbaden: Springer VS. https://doi.org/10.1007/978-3-658-15805-7_10

Trescher, H. (2017c). Wohnräume als pädagogische Herausforderung. Lebenslagen institutionalisiert lebender Menschen mit Behinderung. 2. Aufl. Wiesbaden: VS. https://doi.org/10.1007/978-3-658-14803-4

Trescher, H. (2017d). Disabling Practices. Cogent Social Science, 3(1).

Trescher, H. (2016). Anforderungen an professionell handelnde PädagogInnen in stationären Einrichtungen der Behindertenhilfe. Gemeinsam leben, 24(1), 31-38.

Trescher, H. (2015a). Die Würde des Privaten. Zur Diskussion institutionalisierter Lebensbedingungen von Menschen mit kognitiver Beeinträchtigung. Behindertenpädagogik, 54(2), 136-153.

Trescher, H. (2015b). Inklusion. Zur Dekonstruktion von Diskursteilhabebarrieren im Kontext von Freizeit und Behinderung. Wiesbaden: VS.

Trescher, H. (2013a). Behinderung als demokratische Konstruktion. Zum objektiven Sinn und ,cultutral impact' der UN-Konvention über die Rechte von Menschen mit Behinderungen. Zeitschrift für Inklusion, 7(4).

Trescher, H. (2013b). Kontexte des Lebens. Lebenssituation demenziell erkrankter Menschen im Heim. Wiesbaden: VS.

van Dyk, S., \& Angermüller, J. (2010). Diskursanalyse meets Gouvernementalitätsforschung. Zur Einführung. In S. van Dyk, \& J. Angermüller (Eds.), Diskursanalyse meets Gouvernementalitätsforschung. Perspektiven auf das Verhältnis von Subjekt, Sprache, Macht und Wissen (pp. 7-21). Frankfurt am Main: Campus.

Vanja, C. (2007). Vom Hospital zum Betreuten Wohnen - Die institutionelle Versorgung behinderter Menschen seit dem späten Mittelalter. In G. Cloerkes, \& J.M. Kastl (Eds.), Leben und Arbeiten unter erschwerten Bedingungen. Menschen mit Behinderungen im Netz der Institutionen (pp. 79-100). Heidelberg: Universitätsverlag Winter.

Wansing, G. (2005). Teilhabe an der Gesellschaft. Menschen mit Behinderung zwischen Inklusion und Exklusion. Wiesbaden: Springer. https://doi.org/10.1007/978-3-531-90038-4

Wiese, M. et al. (2012). End-of-Life Care and Dying: Issues Raised by Staff Supporting Older People with Intellectual Disability in Community Living Services. Journal of Applied Research in Intellectual Disabilities, 25, $571-583$. https://doi.org/10.1111/jar.12000

\section{Copyrights}

Copyright for this article is retained by the author(s), with first publication rights granted to the journal.

This is an open-access article distributed under the terms and conditions of the Creative Commons Attribution license which permits unrestricted use, distribution, and reproduction in any medium, provided the original work is properly cited. 